\title{
Effect of Mn on Solubility of Ti-sulfide and Ti-carbosulfide in Ultra-low C Steels
}

\author{
Naomitsu MIZUI, ${ }^{1)}$ Toru TAKAYAMA ${ }^{1)}$ and Kazuyoshi SEKINE ${ }^{21}$ \\ 1) Corporate Reasarch \& Development Laboratories, Sumitomo Metal Industries Ltd., 1-8, Fuso-cho, Amagasaki $660-0891$ \\ Japan. $\quad$ 2) Graduate School of Environment and Information Sciences, Yokohama National University, 79-7, Tokiwadai, \\ Hodogaya-ku, Yokohama 240-8501 Japan.
}

(Received on February 6, 2008; accepted on March 31, 2008)

\begin{abstract}
To clarify the thermodynamic stability of $\mathrm{Ti}_{4} \mathrm{C}_{2} \mathrm{~S}_{2}$ and TiS in ULC Ti-added IF steels, extraction by potentiostatic electrolysis method and chemical analysis were conducted with ULC Ti-added IF steels containing various amounts of $\mathrm{Mn}$ and heated at various temperatures. As the results, the solubilities of $\mathrm{Ti}_{4} \mathrm{C}_{2} \mathrm{~S}_{2}$ and TiS increased with an increase in $\mathrm{Mn}$ content. $\mathrm{Ti}_{4} \mathrm{C}_{2} \mathrm{~S}_{2}$ was more stable than TiS between 950 and $1250^{\circ} \mathrm{C}$. Following solubility products were obtained.
\end{abstract}

$$
\begin{aligned}
& \log [\mathrm{Ti}] \cdot[\mathrm{C}]^{0.5} \cdot[\mathrm{S}]^{0.5}=0.392-7004 / T-(4.783-7401 / T) \cdot[\mathrm{Mn}] \\
& \log [\mathrm{Ti}]^{2 / 3} \cdot[\mathrm{S}]=-0.021-5847 / T-(3.360-5195 / T) \cdot[\mathrm{Mn}] \\
& \text { KEY WORDS: ultra-low C steel; Ti; sulfide; carbosulfide; Mn; solubility. }
\end{aligned}
$$

\section{Introduction}

Ultra-low C (ULC) Ti-stabilized and semi-stabilized cold-rolled sheet steels have been widely applied to automotive body. Fully stabilized steel, so called InterstitialFree (IF) steel, exhibits excellent deep drawability and is applied to deep drawn parts. Semi-stabilized steels exhibits bake-hardenability due to remained solute $\mathrm{C}$ and is applied to exposed panels with dent resistance. Both deep drawability and bake-hardenability are obtained by control of precipitation in the steels. ${ }^{1)}$

In ULC Ti-added steels, TiN, TiS, MnS, $\mathrm{Ti}_{4} \mathrm{C}_{2} \mathrm{~S}_{2}$ and $\mathrm{TiC}$ precipitate. TiN is the most stable and precipitates during cooling after casting. TiC is the most unstable and precipitates after coiling in hot rolling process. As regards the thermodynamic stability of sulfides and carbosulfide, several researchers have reported empirical solubility products. ${ }^{2-10)}$ However there still remained uncertainty due to the variations in the chemical composition of steels used in experiments, the experimental procedures, and analytical methods. Solubility product of $\mathrm{Ti}_{4} \mathrm{C}_{2} \mathrm{~S}_{2}$ and TiS are listed in Table 1. Only the solubility product by Yamashita et al. was simulation result by means of Thermo-Calc and reproduced from the figure in the paper. ${ }^{11)}$ Table 2 shows the list of experimental materials used in each work. Some used low-C steels. Not only $\mathrm{C}$ but also $\mathrm{Mn}$ and Ti contents varied. Iorio and Garrison studied on stainless steel.

Table 1. Solubility products of $\mathrm{Ti}_{4} \mathrm{C}_{2} \mathrm{~S}_{2}$ and TiS in literatures.

\begin{tabular}{|c|l|r|r|r|r|}
\hline \multirow{2}{*}{ No. } & \multirow{2}{*}{ Reference } & \multicolumn{2}{|c|}{$\mathrm{Ti}_{4} \mathrm{C}_{2} \mathrm{~S}_{2}$} & \multicolumn{2}{|c|}{ TiS } \\
\cline { 3 - 6 } & \multicolumn{1}{c|}{$\mathrm{A}$} & \multicolumn{1}{c|}{$\mathrm{B}$} & \multicolumn{1}{c|}{$\mathrm{A}$} & \multicolumn{1}{c|}{$\mathrm{B}$} \\
\hline 1 & Lui $^{2)}$ & 6.500 & -15600 & 8.20 & -17640 \\
\hline 2 & Lui $^{3)}$ & 6.030 & -15310 & 6.24 & -14559 \\
\hline 3 & Subramanian $^{5)}$ & & & 6.75 & -16550 \\
\hline 4 & Subramanian $^{5)}$ & & & 12.22 & -25230 \\
\hline 5 & Yoshinaga $^{6)}$ & -0.780 & -5208 & -2.01 & -3252 \\
\hline 6 & Yang $^{7}$ & 7.900 & -17045 & 5.43 & -13975 \\
\hline 7 & Copreaux $^{8)}$ & 6.320 & -15350 & 6.92 & -16550 \\
\hline 8 & lorio $^{\text {9) }}$ & 5.510 & -14646 & & \\
\hline 9 & Mitsui $^{10)}$ & 4.093 & -12590 & 4.28 & -12587 \\
\hline $10^{*}$ & Yamashita $^{11}$ & 7.313 & -15125 & & \\
\hline
\end{tabular}

$\log [\mathrm{Ti}][\mathrm{C}]^{0.5}[\mathrm{~S}]^{0.5}, \log [\mathrm{Ti}][\mathrm{S}]=\mathrm{A}+\mathrm{B} / \mathrm{T}$

Table 2. Chemical composition of steels for evaluation of solubility of $\mathrm{Ti}_{4} \mathrm{C}_{2} \mathrm{~S}_{2}$ and TiS (mass\%).

\begin{tabular}{|c|c|c|c|c|c|c|c|c|c|}
\hline No. & $\mathrm{C}$ & $\mathrm{Si}$ & $\mathrm{Mn}$ & $\mathrm{P}$ & $\mathrm{S}$ & $\mathrm{Al}$ & $\mathrm{N}$ & $\mathrm{Ti}$ & Others \\
\hline 1 & $500-720$ & 0.253 & $1.430-1.670$ & 0.005 & 100 & 0.018 & 67 & $0.05-0.25$ & \\
\hline 2 & 100 & - & - & - & - & - & - & $0.12-0.38$ & \\
\hline 3 & $8-40$ & 0.006 & $0.066-0.196$ & 0.010 & $40-80$ & 0.005 & 30 & $0.019-0.068$ & \\
\hline 4 & - & - & - & - & - & - & - & - & \\
\hline 5 & $23-27$ & 0.020 & $0.006-0.010$ & 0.002 & $30-175$ & 0.033 & 5 & $0.017-0.028$ & \\
\hline 6 & $27-36$ & 0.005 & $0.081-0.133$ & 0.010 & $28-115$ & 0.045 & 22 & $0.023-0.095$ & \\
\hline 7 & $30-180$ & 0.014 & $0.185-0.210$ & 0.016 & $80-190$ & 0.051 & 28 & $0.047-0.204$ & $\begin{array}{l}\text { Ni:0.06 } \\
\text { Cr:0.03 }\end{array}$ \\
\hline 8 & $0.16-0.2$ & - & - & 0.003 & $5-10$ & - & 3 & $0.009-0.020$ & $\begin{array}{l}\text { Ni:10,Co:13, } \\
\text { Cr:2, Mo: } 1\end{array}$ \\
\hline 9 & - & - & - & - & - & - & - & $0.001-0.05$ & \\
\hline \multicolumn{7}{|c|}{$\mathrm{C}, \mathrm{S}, \mathrm{N}$ in mass ppm., - not available in the paper. } \\
\hline
\end{tabular}


Table 3. Experimental methods for evaluation of solubility of $\mathrm{Ti}_{4} \mathrm{C}_{2} \mathrm{~S}_{2}$ and TiS.

\begin{tabular}{|c|l|l|c|}
\hline No. & \multicolumn{1}{|c|}{ Method } & \multicolumn{1}{|c|}{ Deformation } & Reheating $\left({ }^{\circ} \mathrm{C}\right)$ \\
\hline 1 & EPMA, TEM with extraction replica & Hot rolled above $820^{\circ} \mathrm{C}$ & 1220 \\
\hline 2 & $\begin{array}{l}\text { Sulfidizing in } \mathrm{H}_{2} \mathrm{~S}+\mathrm{H}_{2} \text { gas } \\
\left(\text { by Swisher }^{4}\right)\end{array}$ & Deformation in sheet & $1150-1300$ \\
\hline 3 & $\begin{array}{l}\text { Dissolution temperature measurement by } \\
\text { TEM with extraction replica }\end{array}$ & Cut out from hot bands & $900-1385$ \\
\hline 4 & Diffusion couple & & $1250-1350$ \\
\hline 5 & $\begin{array}{l}\text { Precipitation, extraction by potentiostatic } \\
\text { electrolysis method, and chemical analysis }\end{array}$ & $\begin{array}{l}\text { Rough hot rolled, reheated at } \\
1100^{\circ} \mathrm{C}, \text { hot rolled above } 930^{\circ} \mathrm{C}, \text { air } \\
\text { cooled }\end{array}$ & $1000-1250$ \\
\hline 6 & $\begin{array}{l}\text { Dissolution temperature measurement by } \\
\text { TEM with extraction replica }\end{array}$ & Cut out from ingot & $1100-1350$ \\
\hline 7 & $\begin{array}{l}\text { Precipitation, extraction by potentiostatic } \\
\text { electrolysis method, and chemical analysis }\end{array}$ & Cut out from ingot & $1050-1250$ \\
\hline 8 & $\begin{array}{l}\text { Dissolution temperature measurement by } \\
\text { TEM with extraction replica }\end{array}$ & Commercial processed sheet & $1250-1390$ \\
\hline 9 & Diffusion couple & & $1100-1300$ \\
\hline
\end{tabular}

Table 3 shows the experimental methods. There are 4 types of procedures. The first method is the dissolution temperature measurement by transmission electron microscopic (TEM) observation with extraction replica. The second one is potentiostatic electrolysis method. The third one is diffusion couple. The last one is sulfidizing. It is very important to choose the proper etchant. Otherwise precipitates will be dissolved. Methodology for chemical analysis using electrolytically extracted residue has been discussed in elsewhere. $^{12-14)}$

Recently the computer softwares and database for thermodynamic simulation have been developed. Computer simulation of precipitation in ULC Ti-stabilized steels has been done. Oikawa et $a l .{ }^{15)}$ reviewed the solubility products in the literatures in comparison with their thermodynamic calculation by CALPHAD. They concluded that $\mathrm{Ti}_{4} \mathrm{C}_{2} \mathrm{~S}_{2}$ is more stable than TiS and MnS. They guessed that TiS, the metastable precipitate, easily precipitates during high temperature slab reheating because of the large activation energy for nucleation of $\mathrm{Ti}_{4} \mathrm{C}_{2} \mathrm{~S}_{2}$. Yamashita et al. ${ }^{11)}$ calculated solubility of $\mathrm{Ti}_{4} \mathrm{C}_{2} \mathrm{~S}_{2}$ by means of Thermo-Calc with the Gibbs free energy of formation of $\mathrm{Ti}_{4} \mathrm{C}_{2} \mathrm{~S}_{2}$ by Iorio and Garrison. ${ }^{9)}$ Their calculation results are listed in Table 1. As the results the solubility product of $\mathrm{Ti}_{4} \mathrm{C}_{2} \mathrm{~S}_{2}$ was much larger than those reported previously, and that $\mathrm{Ti}_{4} \mathrm{C}_{2} \mathrm{~S}_{2}$ hardly precipitates in austenite of ULC Ti-added steels. However $\mathrm{Ti}_{4} \mathrm{C}_{2} \mathrm{~S}_{2}$ is often observed in slabs heated below $1100^{\circ} \mathrm{C}$. They explained that $\mathrm{Ti}_{4} \mathrm{C}_{2} \mathrm{~S}_{2}$ is meta-stable but precipitates through strain induced precipitation mechanism. Thus even in the thermodynamic researchers, the stability of $\mathrm{Ti}_{4} \mathrm{C}_{2} \mathrm{~S}_{2}$ and TiS has not been settled.

In the present paper, solubility products of $\mathrm{Ti}_{4} \mathrm{C}_{2} \mathrm{~S}_{2}$ and TiS will be calculated with the chemical analysis data that was already reported. ${ }^{12)}$ Those solubility products will be compared with the solubility products previously reported.

\section{Experimental Procedure}

Ultra-low-C Ti-stabilized steels containing various amount of $\mathrm{Mn}$ were melted in vacuum induction furnace. The chemical compositions are given in Table 4. The ingots were heated at $1200^{\circ} \mathrm{C}$ and then hot forged to slabs above $900^{\circ} \mathrm{C}$. As shown in Fig. 1, the slabs were heated at $1250^{\circ} \mathrm{C}$ for $1 \mathrm{~h}$ and hot rolled to $6 \mathrm{~mm}$ thick plates in the temperature range between 900 and $1000^{\circ} \mathrm{C}$, and subsequently water quenched. The hot-rolled sheets were cut and
Table 4. Chemical compositions of steels (mass\%).

\begin{tabular}{|c|c|c|c|c|c|c|c|c|c|}
\hline Steel & $\mathrm{C}$ & $\mathrm{Si}$ & $\mathrm{Mn}$ & $\mathrm{P}$ & $\mathrm{S}$ & sol.Al & $\mathrm{N}$ & $\mathrm{Ti}$ & $\mathrm{O}$ \\
\hline Q1 & 0.0024 & 0.001 & 0.06 & 0.008 & 0.0065 & 0.041 & 0.0007 & 0.045 & 0.002 \\
\hline Q1 & 0.0023 & 0.002 & 0.18 & 0.008 & 0.0067 & 0.041 & 0.0009 & 0.044 & 0.003 \\
\hline Q3 & 0.0027 & 0.002 & 0.34 & 0.008 & 0.0067 & 0.039 & 0.0008 & 0.046 & 0.002 \\
\hline Q4 & 0.0030 & 0.003 & 0.72 & 0.007 & 0.0064 & 0.042 & 0.0017 & 0.044 & 0.001 \\
\hline
\end{tabular}

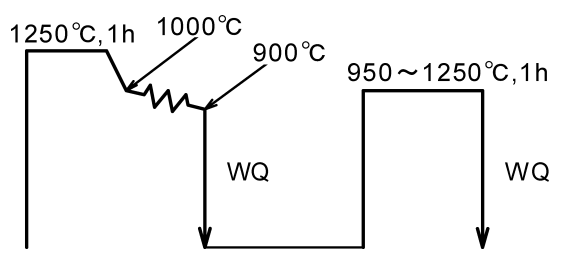

Fig. 1. Experimental procedure.

heated at various temperatures between 950 and $1250^{\circ} \mathrm{C}$ for $1 \mathrm{~h}$ in Ar atmosphere and water quenched. Some plates were heated at $1250^{\circ} \mathrm{C}$ for $1 \mathrm{~h}$, subsequently cooled to $950^{\circ} \mathrm{C}$, kept at the temperature for $1 \mathrm{~h}$ and water quenched.

The sulfides were separated by means of potentiostatic electrolysis method with methanol electrolyte containing $1 \%(\mathrm{~m} / \mathrm{v})$ salicylic acid, $4 \%(\mathrm{v} / \mathrm{v})$ methyl salicylate and $1 \%$ $(\mathrm{m} / \mathrm{v})$ tetra-methyl-ammonium chloride. The $\mathrm{S}$ contents in the sulfides were determined by infrared absorption method after combustion in an induction or by $\mathrm{H}_{2} \mathrm{~S}$ evolution-methylene blue spectrophotometric method. The amounts of metallic elements in separated sulfides were determined by $\mathrm{X}$-ray fluorescence method.

\section{Experimental Results}

The variation in mass fraction of $\mathrm{S}$ as sulfide and carbosulfide are shown in Figs. 2-5. In 0.06 mass\% Mn steel, most of S precipitated as TiS at $1250^{\circ} \mathrm{C}$ as shown in Fig. 2. There remained about 10 mass $\cdot p p m$ solute $\mathrm{S}$. $\mathrm{Ti}_{4} \mathrm{C}_{2} \mathrm{~S}_{2}$ and $\mathrm{MnS}$ precipitated very little. With a decrease in reheating temperature, TiS and solute $\mathrm{S}$ decreased and $\mathrm{Ti}_{4} \mathrm{C}_{2} \mathrm{~S}_{2}$ increased. At $950^{\circ} \mathrm{C}, \mathrm{S}$ as TiS became less than 10 mass $\cdot \mathrm{ppm}$ and most of $\mathrm{S}$ precipitated as $\mathrm{Ti}_{4} \mathrm{C}_{2} \mathrm{~S}_{2}$. In 0.18 mass $\% \mathrm{Mn}$ steel as shown in Fig. 3 and 0.35 mass\% Mn steel as shown in Fig. 4, the fraction of S in various states changed with reheating temperature almost same as that in 0.06 mass $\% \mathrm{Mn}$ steel. Furthermore in case of reheating at $950^{\circ} \mathrm{C}, \mathrm{MnS}$ precipitated more than TiS in 0.35 mass $\%$ Mn steel. In the steel containing 0.72 mass $\% \mathrm{Mn}$ as shown in Fig. 5, MnS precipitated most and TiS precipitated very little in no rela- 


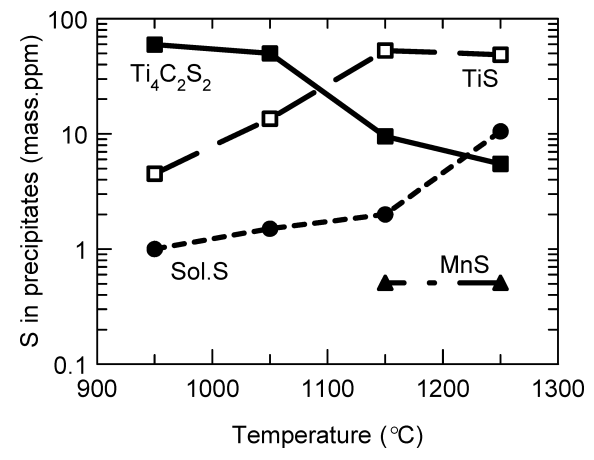

Fig. 2. Effect of reheating temperature on fraction of sulfides in 0.06 mass $\%$ Mn steel.

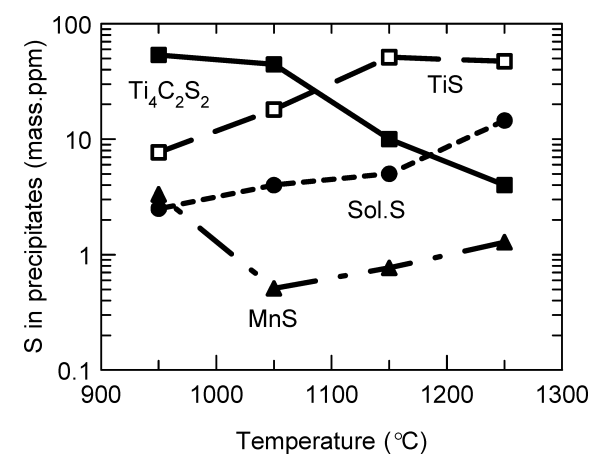

Fig. 3. Effect of reheating temperature on fraction of sulfides in 0.18 mass $\%$ Mn steel.

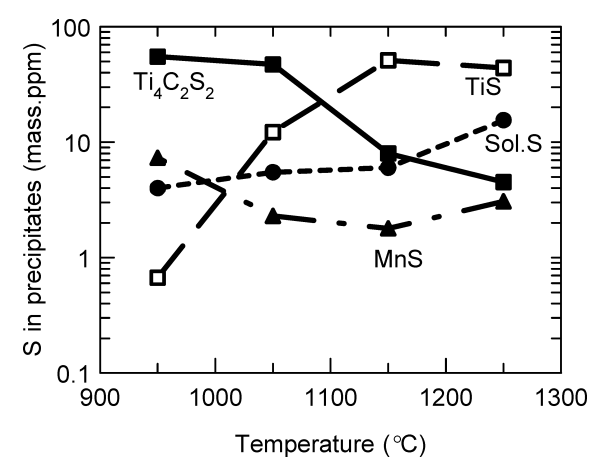

Fig. 4. Effect of reheating temperature on fraction of sulfides in 0.34 mass $\%$ Mn steel.

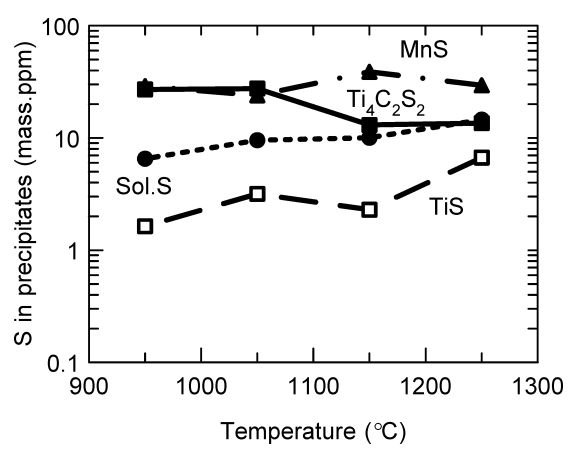

Fig. 5. Effect of reheating temperature on fraction of sulfides in $0.72 \mathrm{mass} \% \mathrm{Mn}$ steel.

tion with reheating temperature. $\mathrm{Ti}_{4} \mathrm{C}_{2} \mathrm{~S}_{2}$ increased with a decrease in reheating temperature and precipitated as much as $\mathrm{MnS}$ at $950^{\circ} \mathrm{C}$.

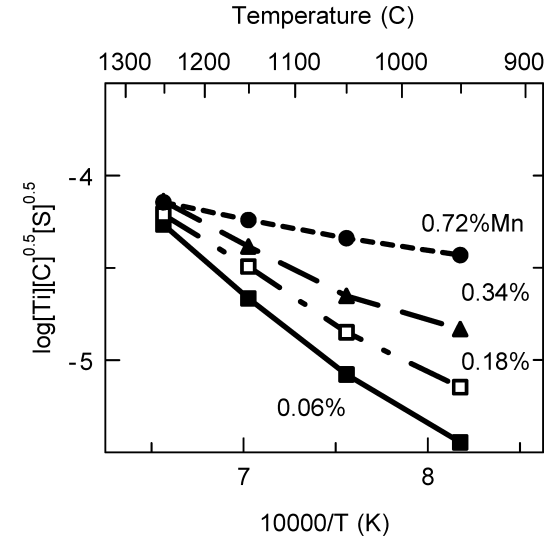

Fig. 6. Solubility product of $\mathrm{Ti}_{4} \mathrm{C}_{2} \mathrm{~S}_{2}$.

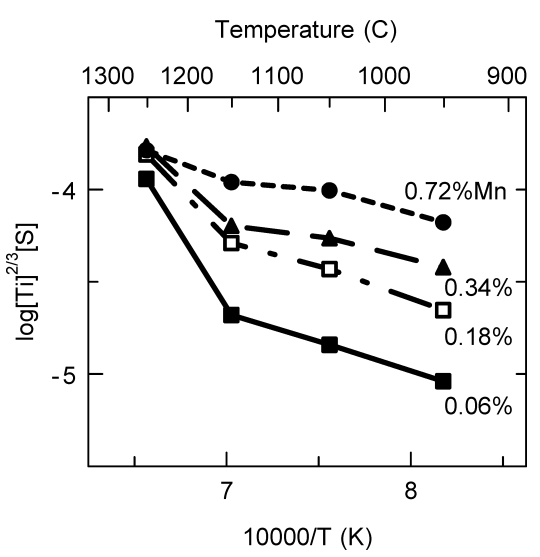

Fig. 7. Solubility product of $\mathrm{Ti}_{2} \mathrm{~S}_{3}$.

\section{Discussion}

\subsection{Solubility Products of $\mathrm{Ti}_{4} \mathrm{C}_{2} \mathrm{~S}_{2}$ and $\mathrm{Ti}_{2} \mathrm{~S}_{3}$}

Solubility products were calculated as followed. The differences between chemical contents and precipitates extracted by potentiostatic electrolysis method were applied to the solute $\mathrm{S}, \mathrm{Ti}$, and $\mathrm{Mn}$ contents. The solute $\mathrm{C}$ content was calculated by using $\mathrm{S}$ as $\mathrm{Ti}_{4} \mathrm{C}_{2} \mathrm{~S}_{2}$, supposing TiC didn't precipitate in austenite. In the present work, all the TiS exhibited $\mathrm{Ti} / \mathrm{S}$ atomic ratio of $2 / 3$. That doesn't mean that $\mathrm{Ti}_{2} \mathrm{~S}_{3}$ precipitated but that Fe solved in TiS. Therefore solubility products of $\mathrm{Ti}_{2} \mathrm{~S}_{3}$ were calculated instead of TiS. The solubility products of $\mathrm{Ti}_{4} \mathrm{C}_{2} \mathrm{~S}_{2}$ and $\mathrm{Ti}_{2} \mathrm{~S}_{3}$ in the steels with various Mn contents and reheated at various temperatures were plotted in Figs. 6 and 7. Both solubility products increased with increases in reheating temperature and $\mathrm{Mn}$ content. If $\mathrm{Ti} / \mathrm{S}$ atomic ratio was ignored and TiS solubility product was calculated, the stability order between $\mathrm{Ti}_{4} \mathrm{C}_{2} \mathrm{~S}_{2}$ and TiS would be different as shown in Fig. 8 .

By using those values of solubility products, the regression analysis has been done for each steel. The results were listed in Table 5. The regression coefficients for $\mathrm{Ti}_{4} \mathrm{C}_{2} \mathrm{~S}_{2}$ and $\mathrm{Ti}_{2} \mathrm{~S}_{3}$ varied with $\mathrm{Mn}$ content as shown in Fig. 9. The absolute values of constant " $A$ " and the coefficient " $B$ " decrease with an increase in $\mathrm{Mn}$ content for both precipitates.

According to Ohtani and Hasebe, ${ }^{16)}$ the effect of Mn content on the solubility products can be expressed as followed. 


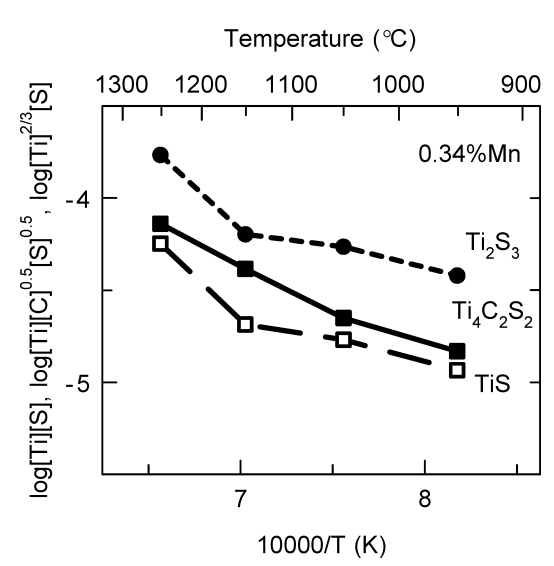

Fig. 8. Comparison in solubility products of $\mathrm{TiS}, \mathrm{Ti}_{4} \mathrm{C}_{2} \mathrm{~S}_{2}$ and $\mathrm{Ti}_{2} \mathrm{~S}_{3}$ in steel containing 0.34 mass $\% \mathrm{Mn}$ and reheated at various temperatures.

Table 5. Results of regression analysis for each steel.

\begin{tabular}{|c|c|c|c|c|c|c|c|}
\hline \multirow{2}{*}{ Steel } & $\mathrm{Mn}$ & \multicolumn{3}{|c|}{$\mathrm{Ti}_{4} \mathrm{C}_{2} \mathrm{~S}_{2}$} & \multicolumn{3}{|c|}{$\mathrm{Ti}_{2} \mathrm{~S}_{3}$} \\
\cline { 3 - 8 } & (mass\%) & $\mathrm{R}$ & $\mathrm{A}$ & $\mathrm{B}$ & $\mathrm{R}$ & $\mathrm{A}$ & $\mathrm{B}$ \\
\hline Q1 & 0.06 & 0.996 & 0.504 & -7323 & 0.908 & -0.038 & -6259 \\
\hline Q2 & 0.18 & 0.997 & -0.382 & -5858 & 0.951 & -0.716 & -4886 \\
\hline Q3 & 0.34 & 0.991 & -1.326 & -4334 & 0.917 & -1.454 & -3697 \\
\hline Q4 & 0.72 & 0.997 & -2.991 & -1773 & 0.977 & -2.330 & -2257 \\
\hline
\end{tabular}

$\log [\mathrm{Ti}][\mathrm{C}]^{0.5}[\mathrm{~S}]^{0.5}, \log \left[\mathrm{TT}^{2 / 2}\right]^{2 / 3}[\mathrm{~S}]=\mathrm{A}+\mathrm{B} / \mathrm{T}, \mathrm{R}$ : multiple correlation coefficient

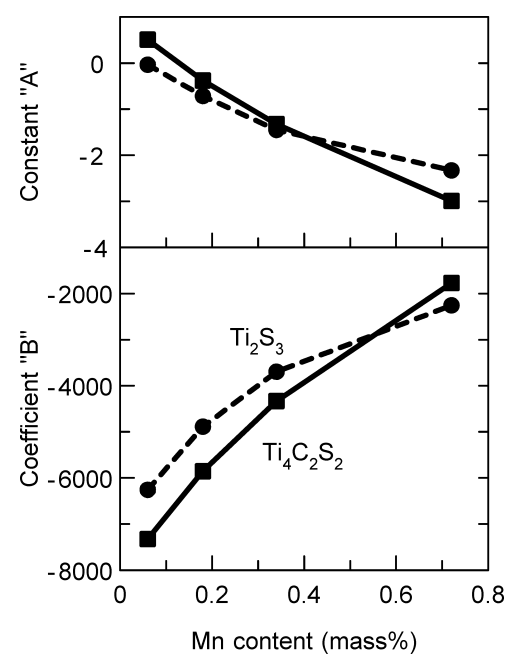

Fig. 9. Variation in regression coefficients for $\mathrm{Ti}_{4} \mathrm{C}_{2} \mathrm{~S}_{2}$ and $\mathrm{Ti}_{2} \mathrm{~S}_{3}$ with Mn content.

$$
\begin{gathered}
\log \left(\mathrm{Ti} \% \cdot \mathrm{C} \% \cdot \mathrm{S} \%{ }^{0.5}\right) \cong A+\frac{B}{T}+\left(C+\frac{D}{T}\right) \cdot \mathrm{Mn} \% \\
\log \left(\mathrm{Ti}^{2 / 3} \cdot \mathrm{S} \%\right) \cong A+\frac{B}{T}+\left(C+\frac{D}{T}\right) \cdot \mathrm{Mn} \%
\end{gathered}
$$

The regression coefficients " $C$ " and " $D$ " give the summation of related interaction parameters.

$$
\begin{aligned}
& W_{\mathrm{TiMn}}^{\gamma}+0.5 \cdot W_{\mathrm{MnC}}^{\gamma}+0.5 \cdot W_{\mathrm{MnS}}^{\gamma} \\
& \quad \cong-\frac{5494 \cdot R \cdot \ln (10)}{55.85} \cdot(D+C \cdot T)=-1883 \cdot(D+C \cdot T)
\end{aligned}
$$

$$
\begin{aligned}
& \frac{2}{3} \cdot W_{\mathrm{TiMn}}^{\gamma}+W_{\mathrm{MnS}}^{\gamma} \\
& \quad \cong-\frac{5494 \cdot R \cdot \ln (10)}{55.85} \cdot(D+C \cdot T)=-1883 \cdot(D+C \cdot T)
\end{aligned}
$$

Several combinations of data have been used for the analysis. The results for $\mathrm{Ti}_{4} \mathrm{C}_{2} \mathrm{~S}_{2}$ and $\mathrm{Ti}_{2} \mathrm{~S}_{3}$ are shown in Tables 6 and 7 respectively. $W_{\mathrm{SUM}}$ means $W_{\mathrm{TiMn}}^{\gamma}+0.5 \cdot W_{\mathrm{MnC}}^{\gamma}+$ $0.5 \cdot W_{\mathrm{MnS}}^{\gamma}$, and $2 / 3 \cdot W_{\mathrm{TiMn}}^{\gamma}+W_{\mathrm{MnS}}^{\gamma}$ respectively. As shown in the tables, the regression analysis with the data of steels containing larger Mn exhibits the smaller summation of interaction parameters.

According to Ohtani and Hillert, ${ }^{17)}$ the interaction parameter can be evaluated from interaction coefficient by following equation.

$$
W_{M X}=R T \cdot \varepsilon_{X}^{M}
$$

The interaction coefficient of $\varepsilon_{\mathrm{C}}^{\mathrm{Mn}}, \varepsilon_{\mathrm{Mn}}^{\mathrm{S}}$ are available in literatures. ${ }^{18,19)}$ Then the interaction parameters are given as following equations.

$$
\begin{gathered}
W_{\mathrm{MnC}}^{\gamma}=-42.152 \ldots \ldots \ldots \ldots \\
W_{\mathrm{MnS}}^{\gamma}=-236.267+0.1064 \cdot T .
\end{gathered}
$$

$W_{\text {TiMn }}^{\gamma}$ has not been clarified yet, but expected smaller than

Table 6. Results of regression analysis for $\mathrm{Ti}_{4} \mathrm{C}_{2} \mathrm{~S}_{2}$.

\begin{tabular}{|c|c|c|c|c|c|c|r|r|r|}
\hline \multirow{2}{*}{ Steel } & \multicolumn{2}{|c|}{ Mn (mass\%) } & \multicolumn{6}{|c|}{ Regression analysis } & \multicolumn{2}{c|}{$\mathrm{W}_{\text {sum }}(\mathrm{kJ} / \mathrm{mol})$} \\
\cline { 2 - 10 } & Range & Average & $\mathrm{R}$ & $\mathrm{A}$ & $\mathrm{B}$ & $\mathrm{C}$ & $\mathrm{D}$ & $1000^{\circ} \mathrm{C}$ & $1200^{\circ} \mathrm{C}$ \\
\hline Q1-Q2 & $0.06-0.18$ & 0.12 & 0.997 & 0.950 & -8060 & -7.433 & 12282 & -5310 & -2511 \\
\hline Q1-Q4 & $0.06-0.72$ & 0.39 & 0.987 & 0.636 & -7489 & -5.221 & 8263 & -3045 & -1079 \\
\hline Q2-Q4 & $0.18-0.72$ & 0.45 & 0.992 & 0.404 & -7065 & -4.801 & 7497 & -2608 & -800 \\
\hline Q3-Q4 & $0.34-0.72$ & 0.53 & 0.993 & 0.173 & -6642 & -4.435 & 6824 & -2219 & -549 \\
\hline
\end{tabular}

Table 7. Results of regression analysis for $\mathrm{Ti}_{2} \mathrm{~S}_{3}$.

\begin{tabular}{|c|c|c|c|r|r|r|r|r|r|}
\hline \multirow{2}{*}{ Steel } & \multicolumn{2}{|c|}{ Mn (mass\%) } & \multicolumn{6}{|c|}{ Regression analysis } & \multicolumn{2}{|c|}{$\mathrm{W}_{\text {SUm }}(\mathrm{kJ} / \mathrm{mol})$} \\
\cline { 2 - 10 } & Range & Average & $\mathrm{R}$ & \multicolumn{1}{|c|}{$\mathrm{A}$} & $\mathrm{B}$ & $\mathrm{C}$ & $\mathrm{D}$ & $1000^{\circ} \mathrm{C}$ & $1200^{\circ} \mathrm{C}$ \\
\hline Q1-Q2 & $0.06-0.18$ & 0.12 & 0.937 & 0.306 & -6952 & -5.718 & 11541 & -8026 & -5872 \\
\hline Q1-Q4 & $0.06-0.72$ & 0.39 & 0.919 & -0.045 & -6144 & -3.375 & 5792 & -2816 & -1545 \\
\hline Q2-Q4 & $0.18-0.72$ & 0.45 & 0.952 & -0.313 & -5550 & -2.892 & 4721 & -1956 & -867 \\
\hline Q3-Q4 & $0.34-0.72$ & 0.53 & 0.944 & -0.669 & -4989 & -2.325 & 3827 & -1631 & -755 \\
\hline
\end{tabular}

$\log \left[\mathrm{Ti}^{2 / 3}[\mathrm{~S}]=\mathrm{A}+\mathrm{B} / \mathrm{T}+(\mathrm{C}+\mathrm{D} / \mathrm{T})[\mathrm{Mn}], \mathrm{R}\right.$ : multiple correlation coefficient 
$W_{\mathrm{MnC}}^{\gamma}$ and $W_{\mathrm{MnS}}^{\gamma}$. $W_{\mathrm{MnS}}^{\gamma}$ is -100.8 and $-79.5 \mathrm{~kJ} / \mathrm{mol}$ at 1000 and $1200^{\circ} \mathrm{C}$ respectively. Even if the formation of $\mathrm{Mn}-\mathrm{C}$ dipole were supposed, the summation of interaction parameters would not exceed $1000 \mathrm{~kJ} / \mathrm{mol}$. The binding energy of $\mathrm{Mn}-\mathrm{C}$ dipole has been reported in the range between -0.26 and $-0.45 \mathrm{eV}^{20-22)}$ The interaction parameter can be given by the following equation. ${ }^{23}$

$$
W_{\mathrm{MnC}}^{\gamma}=R \cdot T \cdot z^{\prime} \cdot\left[1-\exp \left(\frac{-\Delta \varepsilon_{\mathrm{Mn}-\mathrm{C}}}{k_{\mathrm{B}} \cdot T}\right)\right]
$$

Where $-\Delta \varepsilon_{\mathrm{Mn}-\mathrm{C}}$ is the difference in binding energy between $\mathrm{Fe}-\mathrm{C}$ and $\mathrm{Mn}-\mathrm{C} . z^{\prime}$ is the number of binding. In austenite, $z^{\prime}$ is 6 . Even if $-\Delta \varepsilon_{\mathrm{Mn}-\mathrm{C}}$ were $-0.25 \mathrm{eV}, W_{\mathrm{MnC}}^{\gamma}$ would not exceed $600 \mathrm{~kJ} / \mathrm{mol}$. The summation of interaction parameters in steels containing larger amount of $\mathrm{Mn}$ is closer to previously and theoretically determined value than that of low Mn steels. Then the data of high Mn added steel should be chosen. The solute Mn content has been already taken into account in the solubility products. This suggests that the $\mathrm{MnS}$ precipitation affects on the solubility of $\mathrm{Ti}_{4} \mathrm{C}_{2} \mathrm{~S}_{2}$ and $\mathrm{Ti}_{2} \mathrm{~S}_{3}$.

The regression analysis was conducted with the measured solubility products in steels containing MnS more than certain minimum amount. Figure 10 shows the result. The summation of interaction parameters at $1200^{\circ} \mathrm{C}$ increases with an increase in minimum amount of $\mathrm{Mn}$ as $\mathrm{MnS}$. Considering the summation of interaction parameters at higher temperatures, the data of specimens containing $\mathrm{Mn}$ as $\mathrm{MnS}$ more than 2 mass · ppm. Thus following two solubility products were obtained. The solubility product of $\mathrm{Ti}_{4} \mathrm{C}_{2} \mathrm{~S}_{2}$ is similar with that by Yoshinaga et al. ${ }^{6)}$

$$
\begin{aligned}
& \log \left(\mathrm{Ti} \% \cdot \mathrm{C} \%{ }^{0.5} \cdot S \%{ }^{0.5}\right) \\
& \cong 0.392-\frac{7004}{T}-\left(4.783-\frac{7401}{T}\right) \cdot \mathrm{Mn} \%
\end{aligned}
$$

$$
\begin{aligned}
& \log \left(\mathrm{Ti}^{2 / 3} \cdot S \%\right) \\
& \quad \cong-0.021-\frac{5847}{T}-\left(3.360-\frac{5195}{T}\right) \cdot \mathrm{Mn} \%
\end{aligned}
$$

By using coefficients of these solubility products, the summations of interaction parameters $W_{\text {SUM }}$ were calcu-

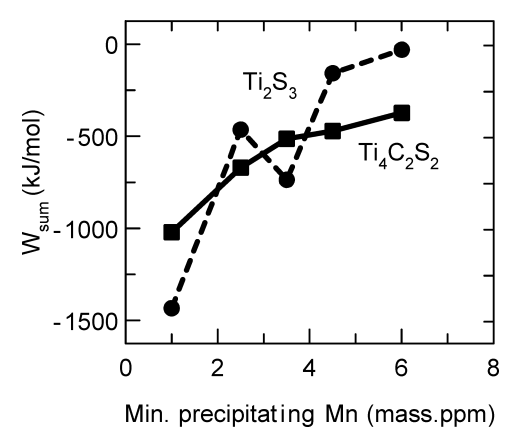

Fig. 10. Variation in summation of interaction parameters at $1200^{\circ} \mathrm{C}$ with minimum precipitating $\mathrm{Mn}$ lated. The variations in $W_{\text {SUM }}$ with temperature were shown in Fig. 11 in comparison with $W^{\gamma}{ }_{\mathrm{MnC}}$ supposing the formation of Mn-C dipole. The $W_{\mathrm{SUM}}$ became as larger as $W_{\mathrm{MnC}}^{\gamma}$ at the temperature as high as $1200^{\circ} \mathrm{C}$. In the lower temperature range, however the $W_{\text {SUM }}$ was much smaller than $W^{\gamma}{ }_{\text {MnC }}$. The reason for such large temperature dependency couldn't be clarified in the present work.

It has often been noted that the solubility products by Yoshinaga et al. ${ }^{6}$ ) exhibit small temperature dependence. Such small temperature dependence seems to be due to the very low Mn content. The mechanism is remained in question.

\subsection{Comparison with Previous Works}

The recalculated solubility product of $\mathrm{Ti}_{4} \mathrm{C}_{2} \mathrm{~S}_{2}$ in 0.3 mass \% Mn steel showed good agreement with that by Yoshinaga et $a l .{ }^{6)}$ For the comparison with the reported solubility product, the relationship between constant " $A$ " and coefficient " $B$ " of all the reported solubility products and present solubility products listed in Table 5 was examined in Fig. 12. There is a linear relationship between two parameters except those by Yamashita et al. ${ }^{11)}$ Even the solubility product measured in stainless steel can be plotted on the correlation line. Such a relation can also be found among solubility products of TiS. The relationship between constant " $A$ " and coefficient " $B$ " can be expressed as followed.

$$
A=a-b \cdot B
$$

All the solubility products give the solubility products similar to " $a$ " at the temperature " $1 / b$ ". Those temperature for $\mathrm{Ti}_{4} \mathrm{C}_{2} \mathrm{~S}_{2}$ and TiS are 1130 and $1250^{\circ} \mathrm{C}$ respectively and

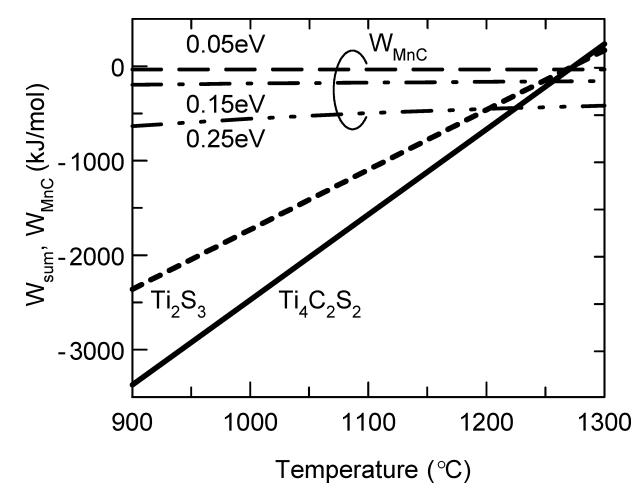

Fig. 11. Variation in summation of interaction parameters with temperature.

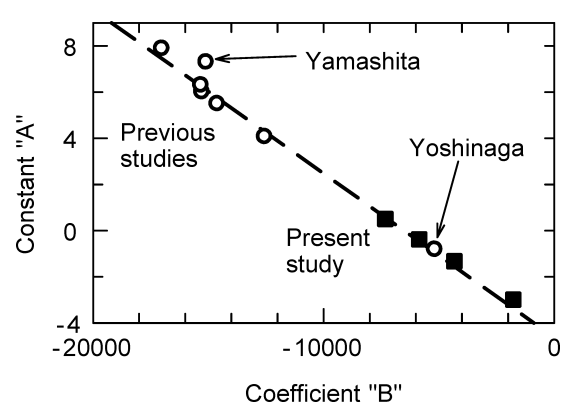

Fig. 12. Relationship between coefficient and constant in solubility products of $\mathrm{Ti}_{4} \mathrm{C}_{2} \mathrm{~S}_{2}$ 
Table 8. Stable phase between 1000 and $1200^{\circ} \mathrm{C}$ and $\mathrm{Ti} / \mathrm{S}$ atomic ration in TiS

\begin{tabular}{|c|l|c|c|}
\hline No. & Reference & Phase & Ti/S \\
\hline 1 & Lui $^{2)}$ & $\mathrm{Ti}_{4} \mathrm{C}_{2} \mathrm{~S}_{2}$ & $\mathrm{NA}$ \\
\hline 2 & Lui $^{3)}$ & $\mathrm{Ti}_{4} \mathrm{C}_{2} \mathrm{~S}_{2}$ & $\mathrm{NA}$ \\
\hline 5 & Yoshinaga $^{6)}$ & $\mathrm{Ti}_{4} \mathrm{C}_{2} \mathrm{~S}_{2}$ & $\mathrm{NA}$ \\
\hline 6 & Yang $^{7}$ & $\mathrm{TiS}$ & 0.88 \\
\hline 7 & Copreaux $^{8)}$ & $\mathrm{TiS}$ & 0.934 \\
\hline 9 & Mitsui $^{10)}$ & $\mathrm{Ti}_{4} \mathrm{C}_{2} \mathrm{~S}_{2}$ & 1.0 \\
\hline 10 & Yamashita $^{11)}$ & $\mathrm{TiS}$ & $\mathrm{NA}$ \\
\hline & Present work & $\mathrm{Ti}_{4} \mathrm{C}_{2} \mathrm{~S}_{2}$ & 0.67 \\
\hline
\end{tabular}

NA: not available

correspond with the precipitation nose of each precipitates. At such temperatures the precipitates become coarse and it would be easier to identify them in no respect of analytical method. True physical meanings should be discussed in elsewhere.

The stable phase between 1000 and $1200^{\circ} \mathrm{C}$ are listed in Table 8. The stable phase doesn't change in this temperature range in any works. From methodological viewpoint, the data by Yoshinaga et al. ${ }^{6}$ and Copreaux et al. ${ }^{8)}$ are more reliable than the others. They used electrolytical extraction. In the present work, electrolytical extraction was also used. It is notable that Copreaux et l. $^{8)}$ and Yang et al. ${ }^{7)}$ calculated $\log [\mathrm{Ti}][\mathrm{S}]$, although $\mathrm{Ti} / \mathrm{S}$ atomic ration were 0.934 and 0.88 respectively. If they would recalculate the solubility products in consideration with $\mathrm{Ti} / \mathrm{S}$ atomic ratio, TiS might be a metastable phase. Sanagi et al. ${ }^{24)}$ reported $\mathrm{Ti} / \mathrm{S}$ atomic ratio varied with reheating temperature. Dupuis et al. $^{25)}$ also pointed out, that the stoichiometries of Ti-carbosulfide is always reported as $\mathrm{Ti}_{4} \mathrm{C}_{2} \mathrm{~S}_{2}$. However $\mathrm{Ti} / \mathrm{S}$ atomic ratio of Ti-sulfide varied, $\left.0.67,{ }^{12}\right) 0.85,{ }^{25)} 0.88,{ }^{7)}$ $0.89{ }^{26)} 1.3 .^{27)}$ These $\mathrm{Ti}_{X} \mathrm{~S}$ seem to be not different phases but TiS with various amount of Fe substituting Ti. As regards Yamashita et al., ${ }^{11)}$ Gibbs free energy of formation $\mathrm{Ti}_{4} \mathrm{C}_{2} \mathrm{~S}_{2}$ by Iorio and Garrison ${ }^{9)}$ should not have been used.

In the commercial production of ULC Ti-stabilized steel, TiS precipitates when slab reheating temperature is higher than $1200^{\circ} \mathrm{C}$. $\mathrm{Ti}_{4} \mathrm{C}_{2} \mathrm{~S}_{2}$ precipitates when slab reheating temperature is lower than $1100^{\circ} \mathrm{C}$. Oikawa et al. ${ }^{15)}$ explained by using Yamada and Niikura ${ }^{28)}$ report, that $\mathrm{Ti}_{4} \mathrm{C}_{2} \mathrm{~S}_{2}$ is stable but the activation energy for nucleation is large. Therefore the meta-stable TiS or MnS precipitates during slab reheating at around $1200^{\circ} \mathrm{C}$. As the slab reheating temperature becomes lower, $\mathrm{Ti}_{4} \mathrm{C}_{2} \mathrm{~S}_{2}$ easily nucleates due to the large free energy change. Plastic deformation also makes the nucleation easier through strain induced precipitation mechanism.

\section{Conclusion}

To clarify the thermodynamic stability of $\mathrm{Ti}_{4} \mathrm{C}_{2} \mathrm{~S}_{2}$ and TiS in ULC Ti-added IF steels, extraction by potentiostatic electrolysis method and chemical analysis were conducted with ULC Ti-added IF steels containing various amounts of $\mathrm{Mn}$ and heated at various temperatures. As the results, the solubilities of $\mathrm{Ti}_{4} \mathrm{C}_{2} \mathrm{~S}_{2}$ and TiS increased with an increase in Mn content. $\mathrm{Ti}_{4} \mathrm{C}_{2} \mathrm{~S}_{2}$ was more stable than TiS between 950 and $1250^{\circ} \mathrm{C}$. Following solubility products were obtained.

$$
\begin{gathered}
\log [\mathrm{Ti}][\mathrm{C}]^{0.5}[\mathrm{~S}]^{0.5}=0.392-7004 / T-\left(4.783-7401 / T^{\#}\right) \cdot[\mathrm{Mn}] \\
\log [\mathrm{Ti}]^{2 / 3}[\mathrm{~S}]=-0.021-5847 / T-\left(3.360-5195 / T^{\#}\right) \cdot[\mathrm{Mn}]
\end{gathered}
$$

\section{Acknowledgements}

The authors greatly appreciate Emeritus Professor at Tohoku University Dr. Taiji Nishizawa for his kind and thoughtful instructions concerning thermodynamics. The authors also appreciate Dr. Shigeharu Hinotani, Dr. Yasuo Inokuma, and Mr. Joh Endo, who had worked on the original analytical research, in Sumitomo Metal Technology. The authors thank Dr. Norio Imai in Sumitomo Metals for his kind advice.

\section{REFERENCES}

1) N. Mizui: Proc. Int. Symp. "Modern LC and ULC Sheet Steels for Cold Forming: Processing and Properties", ed. by W. Bleck, Verlag Mainz, Aachen, Germany, (1998), 169.

2) W. J. Liu, S. Yue and J. J. Jonas: Metall. Mater. Trans. A, 20A (1989), 1907.

3) W. J. Liu, J. J. Jonas, D. Bouchard and C. W. Bale: ISIJ Int., 30 (1990), 985

4) J. H. Swisher: Trans. Metall. Soc. AIME, 242 (1968), 2433.

5) S. V. Subramanian, M. Prikryl, A. Ulabhaje and K. Balasubramanian: Proc. Int. Symp. Interstitial Free Steel Sheet, ed. by A. J. DeArdo, Canadian Inst. Mining Metall. Petro., Montreal, (1991), 15.

6) N. Yoshinaga, K. Ushioda, S. Akamatsu and O. Akisue: ISIJ Int., 34 (1994), 24.

7) X. Yang, J. Dilewijns, Y. Houbaert, D. Vanderschueren and C. Standaert: ISIJ Int., 36 (1996), 1286.

8) J. Copreaux, H. Gaye, J. Henry and S. Lanteri: ECSC Report, EUR 17806 FR, (1997).

9) L. E. Iorio and M. Garrison, Jr.: ISIJ Int., 42 (2002), 545.

10) H. Mitsui, K. Oikawa, I. Oonuma, R. Kainuma and K. Ishida: CAMP-ISIJ, 17 (2004), 1275.

11) T. Yamashita, K. Okuda, E. Yasuhara and K. Satoh: Tetsu-to-Hagané, 93 (2007), 538.

12) S. Hinotani, T. Takayama, N. Mizui, J. Endo and Y. Inokuma: ISIJ Int., 34 (1994), 17.

13) Y. Ishiguri and K. Sato: Mater. Trans. JIM, 37 (1996), 643.

14) T. Ichioka, Y. Sukenobu, Y. Kurakake, M. Aoki and Y. Higo: Nishin Steel Tech. Rep., 79 (1999), 18.

15) K. Oikawa, H. Mitsui and K. Ishida: Mater. Sci. Forum, 500-501 (2005), 711

16) H. Ohtani and M. Hasebe: Bull. Iron Steel Inst. Jpn., 11 (2006), 457.

17) H. Ohtani and M. Hillert: Calphad, 15 (1991), 25.

18) T. Wada, H. Wada, J. F. Elliott and J. Chipman: Metall. Mater. Trans., 3 (1972), 2865

19) E. J. Turkdogan, S. Ignatowicz and J. Pearson: J. Iron Steel Inst., 180 (1955), 349.

20) H. Abe, T. Suzuki and S. Okada: Trans. Iron Steel Inst. Jpn., 25 (1984), 215

21) K. Tagashira, N. Sumita and H. Hayakawa: Mater. Trans. JIM, 30 (1989), 10

22) V. Massardier, E. Le Patezour, M. Soler and J. Merlin: Metall. Mater. Trans. A, 36A (2005), 1745.

23) C. H. Plupis and J. F. Elliott: Acta Metall., 14 (1966), 1019.

24) S. Sanagi, K. Kawasaki and T. Kawano: CAMP-ISIJ, 2 (1989), 2015.

25) G. Dupuis, R. A. Hubert and R. Tailard: 40th MWSP Conf. Proc., ISS, Warrendale, PA, (1998), 117.

26) M. Prikryl, Y. P. Lin and S. V. Subramanian: Scr. Metall., 24 (1990), 375.

27) O. Hamart and S. Lantei: 38th MWSP Cong., Vol. 34, ISS, Warrendale, PA, (1997), 431.

28) K. Yamada and M. Niikura: Tetsu-to-Hagané, 81 (1995), 197. 